\title{
The Co-movement between Cotton and Polyester Prices
}

\author{
JOHN BAFFES \\ THE WORLD BANK \\ GASTON GOHOU \\ UNIVERSITY OF MARYLAND
}

\author{
CORRESPONDENCE: JOHN BAFFES \\ The World Bank \\ 1818 H Street, NW \\ Washington, D.C. 20433 \\ tel: (202) 458-1880 \\ fax: (202) 522-1151 \\ email: jbaffes@worldbank.org
}

\begin{abstract}
This paper examines the price linkages among polyester (the dominant chemical fiber), cotton (the dominant natural fiber), and crude oil (the dominant energy commodity) based on monthly data between 1980 and 2002. The modeling framework incorporates several aspects of the unit root econometrics literature. We find that (i) there is strong co-movement between cotton and polyester prices, well above the comovement observed between these two prices and prices of other primary commodities; (ii) crude oil prices have a stronger effect on polyester prices compared to cotton prices; (iii) price shocks originating in the polyester market are transmitted at much higher speed to the cotton market than vice-versa.
\end{abstract}

World Bank Policy Research Working Paper 3534, March 2005

The Policy Research Working Paper Series disseminates the findings of work in progress to encourage the exchange of ideas about development issues. An objective of the series is to get the findings out quickly, even if the presentations are less than fully polished. The papers carry the names of the authors and should be cited accordingly. The findings, interpretations, and conclusions expressed in this paper are entirely those of the authors. They do not necessarily represent the view of the World Bank, its Executive Directors, or the countries they represent. Policy Research Working Papers are available online at http://econ.worldbank.org.

Presented at the FAO/ESC Commodity Symposium, Rome, December 15-16, 2003. We would like to thank David Hallam, Aasim Husain, Tim Lloyd, John McDermott, Brian Moir, Sam Ouliaris, Sharma Ramesh, Alexander Sarris, and Shangnan Shui for comments and suggestions on earlier drafts of this paper. 


\section{INTRODUCTION}

During the past two centuries cotton has played an important role as the main input for clothing. However, this changed after World War II with the emergence of chemical fibers, which have induced a substantial reduction in cotton's share in total fiber consumption, especially during the last 30 years. Chemical fiber began declining sharply during the early 1970s and has been traded at approximately the same levels with cotton since then. Between 1960 and 1972, for example, the polyester price indicator declined form $\$ 12$ per kilogram to $\$ 2.50$ per kilogram, primarily reflecting technological improvements (and consequently cost reductions) that took place in the chemical fiber industry. After reaching parity with $\mathrm{t}$ cotton, this ratio has increased at an average rate of 1 percent per annum, implying that while cotton and polyester are priced at similar levels, polyester has made small price gains during the past three decades. ${ }^{1}$

This paper focuses on the degree and nature of price linkages between cotton (the dominant natural fiber) and polyester (the dominant chemical fiber) for the past two decades. We also examine whether crude oil (the raw material for polyester) plays any role in explaining cotton and polyester price variability. Our framework is based on analysis which incorporates several aspects of the unit root econometrics literature. We supplement this analysis with the error-correction specification first proposed by Sargan (1964) in the form of an autoregressive distributed lag specification and later reformulated and popularized by Hendry et al. (1983) and more recently by Engle and Grange (1987).

Before proceeding with the model, it is useful to take a brief detour and examine the structure of fiber production (figure 1). ${ }^{2}$ Fibers are divided into two broad categories: natural and man-made (often referred to as chemical). Natural fibers can be further divided into fibers of plant-origin (such as cotton and linen) and fibers of animal-origin (such as wool and silk). Likewise, man-made fibers are divided into inorganic and organic fibers. Inorganic fibers are materials such as ceramic, glass, and carbon (typically not used in fabric production). Most of organic man-made fibers, on the other hand, are used in garment 
and other household products either as substitutes or as complements to natural fibers. Organic fibers are further sub-divided into natural and synthetic polymers. Natural polymers (often called cellulosic) are made from pulp (i.e. wood). The most common natural polymer is viscose, also known as rayon. Synthetic polymers are made from crude oil. The most common synthetic polymers are polyester, acrylic, and polyamide (also known as nylon). Currently, cotton and polyester together account for about two thirds of global fiber consumption.

Between 1960 and 2002, cotton's share in global fiber consumption declined from 68 to 40 percent (figure 2). ${ }^{3}$ Over the same period, chemical (often referred to as man-made) fiber consumption increased at an annual rate of 4.7 percent. Cotton consumption during this period increased by only 1.8 percent annually, implying that that in per capita terms cotton consumption has remained virtually unchanged. The average per capita cotton consumption in 1960-65 was 3.27 kilograms. In 1996-2001, it was 3.16 kilograms. Per capita chemical fiber consumption in the these two periods was 1.75 and 4.52 kilograms, respectively. The share of chemicals in total fiber consumption is currently 57 percent, up from 22 percent in 1960.

Lastly, some remarks on the structure of the cotton and chemical fiber industries. The cotton market is highly competitive, in the sense that a large number of producers operate in the industry with virtually no barriers to entry. World cotton production is around 20 million tons, of which US accounts for about 4 million tons (the second largest producer after China). Global cotton trade is about 6 million tons. The United States, world's largest exporter, accounts for 35 percent of global exports. The US supports its cotton sector through various programs to the tune of $\$ 3$ billion annually. This support increases producers' price by about 50 percent above world price and also puts downward pressure on world prices, given the large US share in global output.

World chemical fiber production reached almost 30 million tons in 2002. Major producers are China (20 percent share) followed by the EU, US, and Taiwan with approximate 
shares of 10 percent each. The structure of the chemical fiber industry used to be oligopolistic in the sense that most of the output was produced by a small number of major oil companies. About 3 decades ago, however, this changed. Today most of the chemical fibers come from new smaller independent companies or companies that used to be part of the big oil companies and later became separate entities. ${ }^{4}$

The remainder of this paper proceeds as follows. The next section describes the main features of the model along with the testing procedures. Without making any a priori judgment or assumption regarding the stationarity properties of the prices. Section III discusses the data and the results. The last section concludes and discusses directions for future research.

\section{THE MODEL}

The model used here has been employed frequently by the law of one price and market integration literature. ${ }^{5}$ It begins with the following regression [e.g. Isard (1977), Ardeni (1989), Mundlak and Larson (1992), Gardner and Brooks (1994)]:

$$
p_{t}^{1}=\mu+\beta_{1} p_{t}^{2}+\varepsilon_{t},
$$

where $p_{t}{ }^{1}$ and $p_{t}^{2}$ denote prices of cotton and polyester, $\mu$ and $\beta_{1}$ are parameters to be estimated while $\varepsilon_{t}$ denotes an $\operatorname{IID}\left(0, \sigma^{2}\right)$ term (more about this assumption later). A one-to-one transmission between the two prices would require that the slope coefficient equals unity and (maybe) the intercept term equals zero. Formally, this can be tested as $H_{0}: \mu+1=\beta_{1}=$ 1. Under $H_{0}$ the deterministic part of (1) becomes $p_{t}{ }^{1}=p_{t}{ }^{2}$, in turn implying that the price differential, $p_{t}{ }^{1}-p t^{2}$, is an $\operatorname{IID}\left(0, \sigma^{2}\right)$ term.

Estimating (1) and testing $H_{0}$ presents two shortcomings. First, the presence of nonstationarity, may invalidate standard econometric tests and thus give misleading results regarding the degree of co-movement between prices. Second, in commodity markets, especially the cases such as cotton and polyester whereby the former is a primary commod- 
ity while the latter is an industrial product, it is unlikely that the two prices will only differ by an $\operatorname{IID}\left(0, \sigma^{2}\right)$ term as $H_{0}$ of (1) dictates. Therefore, $H_{0}$ would be rejected without necessarily ruling out a strong price linkage. Consequently, it is necessary to employ a more general model that imposes no a priori requirements on the stationarity properties of the variables in question and also allows for some flexibility.

With respect to nonstationarity, one can examine the order of integration of the error term in (1) and make inferences regarding the validity of the model. Under nonstationary prices, the existence of a stationary error term implies comovement between the two prices. However, if $\beta_{1} \neq 1$, the uniqueness of the cointegration parameter in the bivariate case implies that the corresponding price differential would be growing and such growth would not be accounted for, although prices may move in a seemingly synchronous manner. Hence, stationarity of the error term of (1) while establishing co-movement, should not be considered as a testable form equivalent to that of the $H_{0}$ of (1) (Barrett 1996).

To account for the non-unity slope coefficient one can restrict the parameters of (1) according to $H_{0}$, in which case the problem is equivalent to testing for a unit root in the following univariate process (Engle and Yoo 1987):

$$
\left(p_{t}^{1}-p_{t}^{2}\right) \sim I(0) .
$$

If the price differential as defined in (2) is stationary, then one can conclude that price signals are transmitted from one market to another, in the long run. ${ }^{6}$ An added advantage of (2) is that it imposes less demanding requirements on the critical values of the stationarity tests since no parameter is estimated. The unitary cointegration restriction has been used often in various contexts. [See for example, Campbell and Shiller (1987) for the present value model and term structure of interest rates; Corbae and Ouliaris (1988) for purchasing power parity; Mishkin (1992) for real interest rates; and Baffes and Shah (1994) for budget deficits.]

The restrictive nature of (1) can be circumvented by introducing a more general 
structure. Following Sargan (1964) we append one lag to (1):

$$
p_{t}^{1}=\mu+\beta_{1} p_{t}^{2}+\beta_{2} p_{t-1}^{2}+\beta_{3} p_{t-1}^{1}+u_{t},
$$

where $u_{t}$ is $\operatorname{IID}\left(0, \sigma^{2}\right)$ and $\left|\beta_{3}\right|<1$. Hendry Pagan, and Sargan (1983) discuss a number of testable hypotheses resulting from corresponding restrictions on the parameter space of (3). The most important one is the long-run proportionality or homogeneity hypothesis, the validity of which ensures that polyester price movements will eventually be transmitted to cotton prices. Such a hypothesis can be tested by the restriction $\Sigma_{\mathrm{i}} \beta_{\mathrm{i}}=1$.

Under long-run proportionality, (3) can be re-parameterized as follows:

$$
\left(p_{t}^{1}-p_{t-1}^{1}\right)=\mu+\left(1-\beta_{3}\right)\left(p_{t-1}^{2}-p_{t-1}^{1}\right)+\beta_{1}\left(p_{t}^{2}-p_{t-1}^{2}\right)+u_{t} \text {. }
$$

Relationship (4) belongs to the family of error-correction models (ECM). Because of the equivalence between cointegration and ECM, stationarity of the price differential (2) implies (4) and vice-versa (Engle and Granger 1987). On the other hand, the restriction $\left|\beta_{3}\right|<1$ implies that $0<1-\beta_{3}<2$. The size of $\beta_{3}$, or alternatively whether $\left(1-\beta_{3}\right)$ falls between zero and one or between one and two describes the nature of convergence (monotonic versus oscillatory).

The main feature of (4) is the economic interpretation of its parameters: $\beta$ indicates how much of a given price change in polyester will be transmitted to cotton within the same period (referred to as initial adjustment, short-run effect, or contemporaneous effect); $\left(1-\beta_{3}\right)$ indicates how much of the price difference between polyester and cotton is eliminated in each subsequent period (referred to as error-correction, speed of adjustment, or feedback effect). The coefficient of the short-run effect can, in theory, take any value. The adjustment coefficient, however, is restricted between zero and two. The closer to unity is $\left(1-\beta_{3}\right)$, the higher the speed at which price convergence will take place. Symmetric with respect to unity values of $\left(1-\beta_{3}\right)$ [e.g. 0.90 and 1.10] indicate that the adjustment speed will be the same but the adjustment path will differ [monotonic in the former and oscillatory in 
the latter case].

Note that $\left(1-\beta_{3}\right)$ different from zero is a necessary and sufficient condition for longrun convergence. However, significantly different from zero $\beta_{1}$ is neither a necessary nor a sufficient condition for long-run price convergence; even if $\beta_{1}=1$ (i.e. perfect short-run adjustment) the series may still drift apart in the long run. A number of other interesting hypotheses can be tested from (4) (for a discussion along with their economic interpretations see Baffes and Ajwad (2001)).

The model outlined above suggests that, given long-run proportionality, the choice of (3) or (4) to recover short- and long-run dynamic price behavior is a matter of stationarity properties. If prices are stationary, (3) would be the preferred structure and long-run proportionality could be tested by restricting the slope parameters to sum to unity. Under non-stationarity, (4) is the preferred structure and long-run proportionality can be tested by examining the stationarity properties of the price differential (Engle and Yoo 1987) or testing whether $\left(1-\beta_{3}\right)$ is different from zero (Phillips and Loretan 1991).

The next task is to transform the information contained in the parameter space so that a succinct interpretation of both short-run and feedback effects (and hence price linkage) can be given. In other words, How long does it take for the price of cotton to adjust to a given price change in polyester and vice-versa? Let $n$ be the period by which $k$ percent of the cumulative adjustment has taken place. In the current period, $n=0, k$ takes the value of $\beta_{1}$ [also it can be written as $1-\left(1-\beta_{1}\right)$ or $\beta_{1}+\left(1-\beta_{1}\right) \beta_{3}{ }^{0}$, which is the short-run impact of $\left(p_{t}{ }^{2}-p_{t-1}\right)$ on $\left(p_{t}{ }^{1}-p_{t-1}{ }^{1}\right)$. When, $n=1, k$ takes the value of $\beta_{1}+\left(1-\beta_{1}\right) \beta_{3}$, which is the impact of the previous period, $\beta_{1}$, plus the feedback effect [it can be expressed as $\left(1-\beta_{1}\right) \beta_{3}$ or $\left.1-\left(1-\beta_{1}\right)\left(1-\beta_{3}\right)\right]$. For $n=2, k$ takes the value of the previous period's adjustment, $\beta_{1}+\left(1-\beta_{1}\right) \beta_{3}$ plus $\left(1-\beta_{3}\right)\left(1-\beta_{1}-(1-\right.$ $\left.\beta_{1}\right) \beta_{3}$ ) [it can be written as 1-(1- $\left.\beta_{1}\right) \beta_{3}{ }^{2}$. Hence, the cumulative adjustment at period $n$ is given by $k=1-\left(1-\beta_{1}\right) \beta_{3^{\mathrm{n}}}$. Alternatively, solving for $n$ gives the number of periods required to achieve a certain level of cumulative adjustment, i.e. $n=\left[\log (1-k)-\log \left(1-\beta_{1}\right)\right] / \log \beta$.

If the long run proportionality hypothesis is rejected, i.e. the price differential in (2) 
contains a unit root, then one can estimate (1) and proceed with the 2-step estimation procedure suggested by Engle and Granger (1987). Correspondingly, if the variables of interest are stationary, the hypothesis that $\Sigma_{\mathrm{i}} \beta_{\mathrm{i}}=1$ would be rejected, in which case one could estimate (3) in an unrestricted form.

\section{DATA AND RESULTS}

The dataset consists of monthly series on cotton and polyester prices covering January 1980 to December 2002, a total of 276 observations. The polyester prices were taken from National Cotton Council (www.cotton.org/econ) and represent averages of quality 1.5 Denier. Cotton data were taken from the USDA's Agricultural Marketing Service database (www.usda.gov/nass) and represent mill delivered prices averaged over 4 markets (color 41, leaf 4, staple 34, group 201-B Mill points.) We also included crude oil prices in some of the regressions (West Texas Intermediate, 40’ API, f.o.b. Midland Texas.) All prices are in US dollars (see figures 3 and 4). The analysis was based on both nominal and real series (deflated by the US CPI.) All three price series are reported in the Appendix tables.

Table 1 reports some summary statistics. (For the remaining of this paper the cotton price is denoted as COT, the polyester price as POL, and the crude oil price as OIL.) Although these statistics should be used as indicative only (due to nonstationarity as it will be shown later), they are helpful in understanding some of the properties of the series. The first observation is that the period averages of cotton and polyester prices are almost identical. Second, based on the coefficient of variation measure, the price of crude oil exhibits much higher variability than cotton and polyester prices while cotton price is more variable than polyester price. However, the price variability gap between cotton and polyester becomes much larger when the Z-statistic is utilized. The Z-statistic, calculated as $\left[\Sigma_{t}\left(P_{t}-\right.\right.$ $\left.\left.P_{t-1}\right)^{2} /(n-1)\right]^{1 / 2}$, is a more appropriate measure of variability when prices contain unit roots. The fact that cotton price variability is much higher than polyester is expected for at least two reasons. First, cotton as a primary commodity is subjected to both demand and supply 
shocks while polyester, an industrial product, is subjected mainly to demand shocks. Second, cotton's price responds quickly to changes in the fundamentals because it is determined in a futures exchange (New York Board of Trade). Prices of polyester, however, are determined through contractual arrangements.

\section{Unit Roots}

Unit root test results based on the augmented Dickey-Fuller (ADF) and the Phillips-Perron (PP) tests are reported in table 2 . The ADF is based on the following regression: $\left(p_{t}-p_{t-1}\right)=\mu$ $+\beta p_{t-1}+\operatorname{lags}\left(p_{t}-p_{t-1}\right)+\varepsilon t$, where $p_{t}$ denotes the series under consideration (Dickey and Fuller 1981). A negative and significantly different from zero value of $\beta$ indicates that $p_{t}$ is $I(0)$. The PP test is similar to the ADF; their difference lies on the treatment of any nuisance serial correlation aside from that generated by the hypothesized unit root (Phillips and Perron 1988; Phillips 1989). To identify the presence of one unit root we test $H_{0}: p_{t}$ is not $I(0)$ against $H_{1}: p_{t}$ is $I(0)$. Trend stationarity can be detected by appending a time trend in the relevant regression. Finally, the significance level of the error-correction coefficient, $\left(1-\beta_{3}\right)$, can serve as cointegration test (Phillips and Loretan 1991).

The first two columns of table 2 report results for all three prices (along with the cotton-polyester price differential) on both levels and logarithms (real and nominal terms) without trend. The next two columns report results for the same tests with trend (i.e. trend stationarity tests). All tests indicate that the price of polyester is nonstationary, regardless of the test used or the way in which the price is expressed. Moreover, differencing it once induces stationarity. Of the total of 32 stationarity tests performed for each commodity, crude oil (5 tests) and cotton (3 tests) indicate either stationarity or trend stationarity.

When we consider the cotton-polyester price differential, there is strong evidence of stationarity, on most occasions at the $1 \%$ level of significance, implying that there exists strong comovement between the 2 prices (note that, in a sense, comovement between the two prices implies stationarity of the price ratio as depicted in figure 5). However, this 
conclusion rests heavily on the assumption that both cotton and polyester prices are nonstationary; otherwise it would just reflect the trivial result that any linear combination of stationary variables is stationary.

To summarize, the results thus far show the following:

- All three prices are non-stationary, thus any conclusions regarding short run dynamics should be derived from an ECM specification.

- The price differential is stationary, with statistics ranging from -3.37 to -4.13 , depending on the way in which the test was performed.

These two findings indicate that there is a strong linkage between the prices of cotton and polyester prices. This linkage was implicitly assumed, when the Director General of the International Rayon and Synthetic Fibres Committee in a letter to the Financial Times on June 12, 2003 complained that "recent increases in cotton subsidies have rigged the market even more dramatically in favor of cotton, depressing demand for every substitute product. The result is industrial plants being kept idle... that were built in legitimate expectation that the competitive advantages of manufactured fibers would create demand to fill the capacity..."

\section{Long-Run Relationship}

To gain more insights with respect to the nature of the long run relationship, we also run regression (1) in a variety of specifications. The first 4 columns of table 3 report results based on nominal prices while the last 4 columns report results based on real prices. Although in both cases the stationarity statistics indicate relatively strong comovement, the explanatory power of the regressions with the deflated series is at least twice as high as that of the nominal series. For the remaining discussion we focus our attention to the real price models.

In almost all cases the cointegration statistics (i.e., ADF and PP) were relatively high, indicating comovement at either the $5 \%$ or the $1 \%$ level of significance. However, two in- 
teresting observations can be made. First, all stationarity statistics (including the DW measure of serial correlation) are higher in the cotton equation compared to all the corresponding stationarity statistics of the polyester equation. Second, the crude oil price coefficient is different from zero in only one of the two cotton equation while it is significant in both polyester equations (the $t$-ratio is also much higher in the latter case). Therefore, on the basis of the long run equations one may conclude that the effect of the polyester price on cotton price is stronger than vice versa. Moreover, when the oil is included in the real price regressions, the cointegration statistics worsen, a result that is consistent for the majority of cases. This observation coupled with the fact that the oil price increases the explanatory power of the model only marginally, indicates that the presence of the oil price removes a portion of the cotton-polyester without necessarily bringing more information. ${ }^{7}$ Note that the mixed results from the inclusion of OIL are very similar to the results derived by an FAO (2001-02, pp. 40-43) report which examined the relationship between crude oil prices and a number of fiber prices (including cotton).

Ignoring the relative performance of the cotton and polyester equations, for a moment, the results from table 3 raise the following important question: How strong is the comovement between cotton and polyester prices relative to other commodities? To answer this question, we regressed cotton and polyester prices on 18 primary commodity prices. ${ }^{8}$ Our intention is to examine whether the comovement between cotton and polyester prices as presented in table 3 is, on average, stronger compared to comovement between these two prices and prices of other commodities.

Comevement of commodities prices has been discussed in different contexts. Granger (1986, p. 217), for example, argued that: "If $x_{t}$ and $y_{t}$ are a pair of prices from a jointly efficient, speculative market, they cannot be cointegrated ... if the two prices were cointegrated, one can be used to forecast the other and this would contradict the efficient market assumption. Thus, for example, gold and silver prices, if generated by an efficient market, cannot move together in the long run." ${ }^{9}$ Pindyck and Rotemberg (1990) studied 
the comovement of 5 primary "unrelated" commodities (wheat, cotton, copper, gold, lumber, and cocoa) and found that even after accounting for all macroeconomic variables that are supposed to affect price movements of these commodities, there still exists unexplained comovement. They offered three explanations for this result: incomplete model, macroeconomic variables are not truly exogenous, and assumption of normality. They also suggested that if these explanations do not account for the "excess comovement" then factors such as 'sunspots', 'bubbles', or simply 'market psychology' may explain it. Studies undertaken by other researchers, however, concluded that when alternative model specifications are used the evidence of excess-comovement becomes weak or even disappears; see, for example, Cashin et al. (1999), Deb et al. (1996), Leybourne et al. (1994), Palaskas (1993), and Palaskas and Varangis (1991).

Figure 6 depicts the adjusted- $R^{2}$ from the logarithmic regression of the cotton price on the prices of the 18 commodities mentioned earlier. The adjusted- $R^{2}$ of the regression of cotton on polyester was 0.78 (column [G], upper panel of table 3 ). The adjusted- $R^{2}$ s of corresponding regressions of cotton on the other 18 commodities ranged between a high of 0.67 (rice) and a low of 0.24 (sugar). The regressions of polyester on the 18 prices yielded remarkably similar results (see figure 7). The adjusted- $R^{2}$ for gold is 0.83 followed by polyester with 0.78 . The lowest is rice with 0.28 . A similar outcome was present when stationarity statistics and $t$-ratios were considered (these results are not reported here).

We also replicated the regression with the 18 commodity prices by adding OIL as an explanatory variable, i.e. we replicated the regression results of column $[\mathrm{H}]$ of table 3 by replacing POL with the 18 commodity prices mentioned earlier. The results were remarkably similar: When cotton is the dependent variable, the adjusted- $R^{2}$ ranges from 0.74 (rice) to 0.33 (tea) compared to 0.78 for the COT regression. When polyester is the dependent variable, the adjusted- $R^{2}$ ranges from 0.84 (gold) to 0.41 (cocoa) compared to 0.82 (second highest after gold) for POL regression. ${ }^{10}$

These findings establish three more results: 
- The comovement between cotton and polyester prices is much higher than what is typically observed when these two prices are compared to 18 other highly traded primary commodities. Thus, the comovement reflects factors specific to these markets, in addition to factors affecting all commodities.

- The econometric evidence shows that the effect of polyester price changes on cotton price changes is stronger than vice-versa.

- Crude oil price appears to affect a stronger affect on polyester price than on cotton price (as it would be expected since it is used as an input to produce polyester). This result, however, was not uniform across many models, a finding consistent with earlier results by FAO (2001-02, p. 40-43).

\section{Short-Run Dynamics}

The last step of our analysis examines the short-run dynamics. Although there are various ways in which error correction models can be expressed, we have chosen the specifications consistent with the models that exhibited satisfactory performance. Table 4 reports results from 12 ECM specifications. The error correction term (i.e. lagged error term) of the first two columns correspond to the cotton-polyester price differential as specified in equation (4). The specification of the first column implies that the price of oil affects neither the long run equilibrium nor the short run dynamics. The specification of the second column implies that oil affects the short run dynamics but not the long run equilibrium. The remaining 4 columns report results corresponding to the four long run equilibrium models reported in the last 4 columns of table 3. Correspondingly, the error correction terms are the lagged error terms of these regressions. The price of oil enters the short run dynamics only when it is included in the long run specification.

In most cases the error-correction term was significant at the $1 \%$ level, a finding that further confirms the existence of a long run relationship. On the other hand, the explanatory power of all models is much lower than the cointegration regressions. For example, 
the adjusted $R^{2} \mathrm{~s}$ range between 0.04 and 0.06 for the cotton regressions and between 0.01 and 0.04 for the polyester regressions. To some extent, this was expected given the large gap between cotton and polyester price variability according to the $z$-statistic. It is also the case that models with differenced variables typically yield lower $R^{2} \mathrm{~s}$ than their counterparts in levels.

A number of noteworthy observations emerge from the error corrections models. First, the adjustment coefficient of the error correction terms is higher in the cotton equations (upper panel) than the polyester equations (lower panel). For example, in the first two models the adjustment coefficient is 0.08 for cotton compared to 0.03 for polyester. That coupled with the higher short run effect ( 0.28 versus 0.04$)$ implies that shocks originating in the polyester market are transmitted at much higher speeds to the cotton market than vice-versa. For example, based on the coefficients of the first two columns, within a 3-month period, only $14 \%$ of a cotton price change will be reflected in the price of polyester. However, $44 \%$ of a polyester price change will be reflected in the price of cotton within a 3-month period. Note also that a significant error correction coefficient implies Granger causality.

The results of the error correction models corresponding to the regressions in levels (columns 3 and 4) are remarkably similar in magnitude to those reported in the first two columns. The two short run coefficients are 0.27 and 0.28 while the adjustment coefficients are 0.28 in both cases, in turn implying almost identical adjustment effects. The same holds for the logarithmic version of the cotton equation (upper panel, last two columns): adjustment coefficient 0.08 in both cases and sort run effect 0.25 and 0.27 . The polyester equation, however, indicated no adjustment at all. Two further results emerge from the dynamic regressions:

- The ECM specifications show that the short run effects are less pronounced compared to the long run convergence.

- The speed at which the price signals are transmitted from the polyester market to 
the cotton market is much higher than vice-versa.

- As was the case in the long run regressions, results from the inclusion of crude oil are mixed.

\section{CONCLUSIONS AND FURTHER RESEARCH}

This paper examined the linkages between the prices of cotton and polyester. These two commodities account for almost two-thirds of global fiber consumption. However, during the last 4 decades, cotton's share declined from 68 percent to 40 percent. First we investigated whether a long-run relationship between these two prices exists and how strong it is. We found that not only such relationship exists but it is much stronger than the price links between cotton/polyester prices and 18 other primary commodities.

The error correction models further confirm the existence of the long-run relationship. Furthermore, signals originating from the polyester market are transmitted at much higher speeds to the cotton market than in the reverse direction, therefore concluding that cotton prices follow polyester prices.

This paper was the first step to examine the relationship between the price of cotton (a primary commodity) and polyester (an industrial product), both of which are used as inputs in the production of textiles. There are a number of issues to be further investigated. First, the short-run dynamics must be examined more extensively through the Johansen (1988) procedure so the effect of crude oil is better understood. Second, the analysis should be supplemented by similar analyses in other countries, especially in East Asia, where most of cotton and chemical fiber trade (and hence textile production) takes place. Finally, the results of these models should feed into the ultimate question: What are the reasons behind cotton share's decline in total fiber consumption? 


\section{ENDNOTES}

1 One likely reason for this relative price increase may have been the quality improvements of chemical fiber products.

${ }^{2}$ For details of the structure of the cotton market see Baffes (2004).

3 The increase of the chemical fiber share in total fiber consumption in the second half of the $20^{\text {th }}$ century mirrors the increase in cotton's share in total fiber consumption during the first half of the $1^{\text {th }}$ century (Baffes 2005). Back then, cotton displaced wool and to a limited extend linen.

4 The costs of setting up a smaller chemical fiber company is in the neighborhood of $\$ 100$ million.

${ }^{5}$ For a detailed literature review of the law of one price, market integration, and market efficiency literature see Fackler and Goodwin (2001).

${ }^{6}$ If the cointegration parameter is unity, it is irrelevant whether (1) or (2) is used to uncover the long run relationship as long as the sample is sufficiently large. This is the case because as the sample size increases (1) will yield a slope coefficient equal to unity. However, in small samples, this may not be necessarily the case. For example, Ardeni (1989) using equation (1) in logarithms for a number of internationally traded primary commodities found that in the majority of cases there was not cointegration, thus rejecting the law of one price. Baffes (1991), on the other hand, by using the same data set found that in the majority of cases the price differential was stationary, thus concluding in favor of the law of one price.

7 The proper way to test this, however, is Johansen's (1988) procedure.

8 The 18 commodities included in this part of our analysis are: cocoa, coffee arabica, coffee robusta, tea, sugar, rice, maize, sorghum, palm oil, soybean oil, soybean meal, coconut oil, copper, lead, iron ore, fertilizer TSP, silver, and gold (World Bank).

9 Granger's (1986) statement linking cointegration with the efficient market hypothesis generated a vast amount of literature that examined the comovement of exchange rates as means to test the efficient market hypothesis in foreign exchange transactions. However, most of this literature was based on the flawed assumption that exchange rates are two different assets (see Baffes (1994) for a critical review of that literature).

10 OIL was significantly different from zero (1\% level) in 10 out of the 18 regressions when COT was the dependent variable. When POL was the dependent variable, OIL was significant in all but one case. Again, these results mirror the results presented in the last column of table 3. 
Table 1: Summary Statistics

\begin{tabular}{|c|c|c|c|c|c|}
\hline & MEAN & $\begin{array}{l}\text { COEFFICIENT } \\
\text { OF VARIATION }\end{array}$ & Z-STATISTIC & KURTOSIS & SKEWNESS \\
\hline \multicolumn{6}{|c|}{ NOMINAL PRICES } \\
\hline COT & 71.32 & 19.44 & 4.30 & 3.67 & 0.08 \\
\hline POL & 71.59 & 13.95 & 1.59 & 2.43 & -0.06 \\
\hline OIL & 23.58 & 29.15 & 1.68 & 2.18 & 0.46 \\
\hline COT-POL & -0.27 & & 4.46 & 2.38 & -0.01 \\
\hline \multicolumn{6}{|c|}{ REAL PRICES } \\
\hline COT & 18.99 & 34.08 & 1.20 & 3.67 & 0.68 \\
\hline POL & 19.04 & 30.58 & 0.46 & 2.47 & 0.37 \\
\hline OIL & 6.41 & 50.34 & 0.44 & 3.79 & 1.33 \\
\hline COT-POL & -0.05 & & 1.25 & 2.81 & 0.08 \\
\hline
\end{tabular}

Notes: The Z-statistic is a measure of variability of the first differences, the proper measure of variability for nonstationary variable. It is calculated as the square root of the sum of squared first differences divided by the sample size. Kurtosis and skewness give additional information on the "shape" of a probability distribution. Kurtosis with a value lower than 3, indicates distribution with fat or short tails; greater than 3 indicates distribution with slim or long tails; the distribution is normally distributed is kurtosis equals 3 . For a normally distributed variables skewness equals 0 ; if it is less than 0 , the distribution is left skewed; if it is more than 0 it is right skewed. 
Table 2: Unit Root Tests

\begin{tabular}{|c|c|c|c|c|c|c|}
\hline & \multicolumn{4}{|c|}{ LEVELS } & & \\
\hline & \multicolumn{2}{|c|}{ WITHOUT TREND } & \multicolumn{2}{|c|}{ WITH TREND } & \multicolumn{2}{|c|}{ FIRST DIFFERENCES } \\
\hline & ADF & PP & ADF & PP & ADF & PP \\
\hline \multicolumn{7}{|c|}{ LEVELS/NOMINAL PRICES } \\
\hline COT & -2.29 & $-2.69^{*}$ & -2.58 & -2.99 & $-13.97^{* * *}$ & $-13.90^{* * *}$ \\
\hline POL & -1.17 & -1.71 & -1.87 & -2.31 & $-13.34^{* * *}$ & $-13.79^{* * *}$ \\
\hline OIL & $-2.50^{*}$ & $-2.80^{*}$ & -2.22 & -2.52 & $-11.80^{* * *}$ & $-11.41^{* * *}$ \\
\hline COT-POL & $-3.38^{* *}$ & $-3.77^{* * *}$ & $-3.37^{*}$ & $-3.76^{* *}$ & & \\
\hline \multicolumn{7}{|c|}{ LEVELS/REAL PRICES } \\
\hline COT & -2.00 & -2.06 & -3.12 & $-3.37^{*}$ & $-14.62^{* * *}$ & $-14.57^{* * *}$ \\
\hline POL & -0.94 & -1.04 & -1.65 & -2.13 & $-14.61^{* * *}$ & $-14.95^{* * *}$ \\
\hline OIL & $-3.44^{* *}$ & $-3.33^{* *}$ & -2.64 & -2.75 & $-11.31^{* * *}$ & $-10.84^{* * *}$ \\
\hline COT-POL & $-3.87^{* * *}$ & $-4.13^{* * *}$ & $-3.86^{* *}$ & $-4.12^{* * *}$ & & \\
\hline \multicolumn{7}{|c|}{ LOGARITHMS/NOMINAL PRICES } \\
\hline COT & -2.42 & -2.56 & -2.79 & -2.96 & $-15.40^{* * *}$ & $-15.38^{* * *}$ \\
\hline POL & -1.09 & -1.61 & -1.84 & -2.27 & $-13.40^{* * *}$ & $-13.88^{* * *}$ \\
\hline OIL & -2.50 & $-2.80^{*}$ & -2.24 & -2.62 & $-12.24^{* * *}$ & $-11.94^{* * *}$ \\
\hline COT-POL & $-3.85^{* * *}$ & $-3.97^{* * *}$ & $-3.86^{* *}$ & $-3.97^{* * *}$ & & \\
\hline \multicolumn{7}{|c|}{ LOGARITHMS/REAL PRICES } \\
\hline COT & -1.41 & -1.42 & -2.99 & $-3.16^{*}$ & $-15.42^{* * *}$ & $-15.37^{* * *}$ \\
\hline POL & -0.43 & -0.65 & -1.61 & -2.12 & $-13.91^{* * *}$ & $-14.35^{* * *}$ \\
\hline OIL & -2.47 & -2.54 & -2.17 & -2.50 & $-12.30^{* * *}$ & $-12.01^{* * *}$ \\
\hline COT-POL & $-3.82^{* * *}$ & $-3.92^{* * *}$ & $-3.84^{* * *}$ & $-3.94^{* * *}$ & & \\
\hline
\end{tabular}

Notes: ADF and PP denote the Augmented Dickey-Fuller and Phillips-Perron unit root tests. One $\left(^{*}\right)$, two, $\left.{ }^{* *}\right)$, and three $\left.{ }^{* * *}\right)$ asterisks indicate rejection of unit root at the $10 \%, 5 \%$, and $1 \%$ level of significance respectively. The interpolated critical values are: $-3.46(1 \%),-2.88(55)$, and $-2.57(1 \%)$ for the tests without trend and $-3.99(1 \%),-3.43(5 \%)$, and $-3.13(10 \%)$ for the regressions with trend. 
Table 3: Long-Run Price Relationship

\begin{tabular}{|c|c|c|c|c|c|c|c|c|}
\hline & \multicolumn{4}{|c|}{ NOMINAL PRICES } & \multicolumn{4}{|c|}{ REAL PRICES } \\
\hline & \multicolumn{2}{|c|}{----- LEVELS ----- } & \multicolumn{2}{|c|}{--- LOGARITHMS --- } & \multicolumn{2}{|c|}{----- LEVELS ----- } & \multicolumn{2}{|c|}{--- LOGARITHMS --- } \\
\hline & [A] & [B] & {$[\mathrm{C}]$} & [D] & [E] & {$[\mathrm{F}]$} & [G] & {$[\mathrm{H}]$} \\
\hline \multicolumn{9}{|c|}{ COT $_{\mathrm{t}}$ IS THE DEPENDENT VARIABLE } \\
\hline$\mu$ & $\begin{array}{l}10.51^{*} \\
(12.80)\end{array}$ & $\begin{array}{l}10.46^{*} \\
(10.46)\end{array}$ & $\begin{array}{c}0.63^{*} \\
(2.10)\end{array}$ & $\begin{array}{c}0.67^{*} \\
(2.20)\end{array}$ & $\begin{array}{c}0.08 \\
(0.13)\end{array}$ & $\begin{array}{c}0.77 \\
(1.25)\end{array}$ & $\begin{array}{c}0.02 \\
(0.17)\end{array}$ & $\begin{array}{c}0.02 \\
(0.15)\end{array}$ \\
\hline POLt & $\begin{array}{c}0.85^{*} \\
(2.19)\end{array}$ & $\begin{array}{c}0.85^{*} \\
(2.06)\end{array}$ & $\begin{array}{c}0.85^{*} \\
(12.15)\end{array}$ & $\begin{array}{c}0.85^{*} \\
(12.11)\end{array}$ & $\begin{array}{c}0.99^{*} \\
(32.93)\end{array}$ & $\begin{array}{l}0.85^{*} \\
(17.07)\end{array}$ & $\begin{array}{l}0.99^{*} \\
(30.95)\end{array}$ & $\begin{array}{l}0.99^{*} \\
(21.36)\end{array}$ \\
\hline OILt & - & $\begin{array}{c}0.00 \\
(0.03)\end{array}$ & - & $\begin{array}{l}-0.03 \\
(-0.74)\end{array}$ & - & $\begin{array}{c}0.33^{*} \\
(3.72)\end{array}$ & - & $\begin{array}{l}-0.00 \\
(-0.01)\end{array}$ \\
\hline$D W$ & 0.16 & 0.16 & 0.18 & 0.17 & 0.18 & 0.20 & 0.18 & 0.18 \\
\hline$A D F$ & $-3.32 @ @$ & $-3.32 @$ & $-3.40^{\circledR}$ & $-3.42^{@ @ ~}$ & $-3.88^{@ @ @ ~}$ & -3.79@@@ & $-3.45^{@ @ ~}$ & $-3.45^{@ @ ~}$ \\
\hline$P P$ & $-3.71^{@ @ @ ~}$ & $-3.71^{@ @ ~}$ & $-3.56^{@ @ ~}$ & $-3.58 @ @$ & -4.13@@@ & $-4.05^{@ @ @ ~}$ & $-3.61^{@ @ @ ~}$ & $-3.61^{@ @ @ ~}$ \\
\hline$R^{2}-a d j$ & 0.37 & 0.37 & 0.35 & 0.35 & 0.80 & 0.81 & 0.78 & 0.78 \\
\hline \multicolumn{9}{|c|}{ POL $t$ IS THE DEPENDENT VARIABLE } \\
\hline$\mu$ & $\begin{array}{l}40.16^{*} \\
(16.06)\end{array}$ & $\begin{array}{l}37.58^{*} \\
(2.87)\end{array}$ & $\begin{array}{c}2.51^{*} \\
(17.41)\end{array}$ & $\begin{array}{c}2.34^{*} \\
(14.92)\end{array}$ & $\begin{array}{c}3.77^{*} \\
(7.71)\end{array}$ & $\begin{array}{c}4.24^{*} \\
(9.28)\end{array}$ & $\begin{array}{c}0.63^{*} \\
(8.57)\end{array}$ & $\begin{array}{l}0.73^{*} \\
(10.89)\end{array}$ \\
\hline $\mathrm{COT}_{t}$ & $\begin{array}{c}0.44^{*} \\
(12.80)\end{array}$ & $\begin{array}{c}0.44^{*} \\
(12.65)\end{array}$ & $\begin{array}{c}0.41^{*} \\
(12.15)\end{array}$ & $\begin{array}{c}0.41^{*} \\
(12.11)\end{array}$ & $\begin{array}{c}0.80^{*} \\
(32.93)\end{array}$ & $\begin{array}{l}0.61^{*} \\
(17.07)\end{array}$ & $\begin{array}{l}0.79^{*} \\
(30.95)\end{array}$ & $\begin{array}{l}0.63^{*} \\
(21.36)\end{array}$ \\
\hline OILt & - & $\begin{array}{c}0.13 \\
(1.81)\end{array}$ & - & $\begin{array}{c}0.06^{*} \\
(2.59)\end{array}$ & - & $\begin{array}{l}0.50^{*} \\
(6.95)\end{array}$ & - & $\begin{array}{l}0.19^{*} \\
(8.16)\end{array}$ \\
\hline$D W$ & 0.09 & 0.09 & 0.09 & 0.09 & 0.16 & 0.12 & 0.14 & 0.12 \\
\hline$A D F$ & $-2.65^{\Theta}$ & $-2.70^{\oplus}$ & $-2.61^{@}$ & $-2.66^{@}$ & $-3.42^{@ @ ~}$ & $-3.28 @$ & $-3.15^{@ @ ~}$ & $-3.07 @$ \\
\hline$P P$ & $-2.98 @$ & $-3.03^{\Theta}$ & $-2.80^{\circledR}$ & $-2.89^{\oplus}$ & $-3.67 @ @$ & $-3.57 @ @$ & $-3.28^{\oplus}$ & $-3.33^{@} @$ \\
\hline$R^{2}-a d j$ & 0.37 & 0.37 & 0.35 & 0.36 & 0.80 & 0.83 & 0.78 & 0.82 \\
\hline
\end{tabular}

Notes: ADF and PP denote the Augmented Dickey-Fuller and Phillips-Perron unit root tests. DW is the Durbin-Watson measure of serial correlation. The numbers in parentheses are $t$-ratios. One $\left(^{*}\right)$ asterisk indicates that the coefficient is statistically different from zero at the $1 \%$ level. One $\left({ }^{\circledR}\right)$, two, $\left({ }^{(@)}\right)$, and three $\left({ }^{@ @}\right)$ indicate rejection of unit root at the $10 \%, 5 \%$, and $1 \%$ level of significance respectively. " - " means that the variable was not included in the regression. 
Table 4: Short Run Dynamics (real prices)

\begin{tabular}{|c|c|c|c|c|c|c|}
\hline & \multicolumn{4}{|c|}{ LEVELS } & \multicolumn{2}{|c|}{ LOGARITHMS } \\
\hline & [A] & [B] & {$[\mathrm{C}]$} & [D] & [F] & [G] \\
\hline \multicolumn{7}{|c|}{$\triangle$ COT $_{\mathrm{t}}$ IS THE DEPENDENT VARIABLE } \\
\hline$\mu$ & $\begin{array}{c}-0.08 \\
(-1.10)\end{array}$ & $\begin{array}{c}-0.10 \\
(-1.37)\end{array}$ & $\begin{array}{c}-0.77 \\
(-1.05)\end{array}$ & $\begin{array}{c}-0.10 \\
(-1.31)\end{array}$ & $\begin{array}{c}-0.01 \\
(-1.02)\end{array}$ & $\begin{array}{c}-0.01 \\
(-1.18)\end{array}$ \\
\hline$\triangle P O L_{t}$ & $\begin{array}{c}0.28 \\
(1.16)\end{array}$ & $\begin{array}{c}0.28 \\
(1.79)\end{array}$ & $\begin{array}{c}0.28 \\
(1.76)\end{array}$ & $\begin{array}{c}0.27 \\
(1.74)\end{array}$ & $\begin{array}{c}0.25 \\
(1.31)\end{array}$ & $\begin{array}{c}0.27 \\
(1.45)\end{array}$ \\
\hline$\Delta O I L_{t}$ & - & $\begin{array}{l}-0.45^{*} \\
(-2.84)\end{array}$ & - & $\begin{array}{l}-0.44^{*} \\
(-2.79)\end{array}$ & - & $\begin{array}{l}-0.16^{*} \\
(-2.93)\end{array}$ \\
\hline$E R R O R_{t-1}$ & $\begin{array}{c}0.08^{*} \\
(3.13)\end{array}$ & $\begin{array}{l}0.08^{*} \\
(3.07)\end{array}$ & $\begin{array}{c}0.08^{*} \\
(3.14)\end{array}$ & $\begin{array}{c}0.08^{*} \\
(3.03)\end{array}$ & $\begin{array}{c}0.08^{*} \\
(3.36)\end{array}$ & $\begin{array}{c}0.08^{*} \\
(3.36)\end{array}$ \\
\hline$D W$ & 1.66 & 1.62 & 1.66 & 1.62 & 1.79 & 1.72 \\
\hline$R^{2}-a d j$ & 0.04 & 0.06 & 0.04 & 0.06 & 0.04 & 0.06 \\
\hline \multicolumn{7}{|c|}{$\triangle P O L t$ IS THE DEPENDENT VARIABLE } \\
\hline$\mu$ & $\begin{array}{c}-0.06 \\
(-2.13)\end{array}$ & $\begin{array}{c}-0.06 \\
(-2.08)\end{array}$ & $\begin{array}{c}-0.06 \\
(-2.18)\end{array}$ & $\begin{array}{c}-0.06 \\
(-2.14)\end{array}$ & $\begin{array}{c}-0.01 \\
(-2.48)\end{array}$ & $\begin{array}{c}-0.01 \\
(-2.41)\end{array}$ \\
\hline$\Delta C O T_{t}$ & $\begin{array}{c}0.04 \\
(1.76)\end{array}$ & $\begin{array}{c}0.04 \\
(1.79)\end{array}$ & $\begin{array}{c}0.04 \\
(1.76)\end{array}$ & $\begin{array}{c}0.04 \\
(1.74)\end{array}$ & $\begin{array}{c}0.03 \\
(1.31)\end{array}$ & $\begin{array}{c}0.03 \\
(1.45)\end{array}$ \\
\hline$\Delta O I L_{t}$ & - & $\begin{array}{c}0.02 \\
(0.32)\end{array}$ & - & $\begin{array}{c}0.01 \\
(0.21)\end{array}$ & - & $\begin{array}{c}0.02 \\
(0.95)\end{array}$ \\
\hline$E R R O R_{t-1}$ & $\begin{array}{l}0.03^{*} \\
(3.31)\end{array}$ & $\begin{array}{l}0.03^{*} \\
(3.30)\end{array}$ & $\begin{array}{c}0.03^{*} \\
(3.30)\end{array}$ & $\begin{array}{l}0.03^{*} \\
(3.02)\end{array}$ & $\begin{array}{c}0.01 \\
(0.99)\end{array}$ & $\begin{array}{c}0.01 \\
(0.97)\end{array}$ \\
\hline$D W$ & 1.78 & 0.78 & 1.78 & 1.78 & 1.67 & 0.66 \\
\hline$R^{2}$-adj & 0.04 & 0.03 & 0.04 & 0.03 & 0.01 & 0.01 \\
\hline
\end{tabular}

Notes: The ERROR $t_{t-1}$ in $[\mathrm{A}]$ and $[\mathrm{B}]$ corresponds to the lagged price differential (COTt-1-POLt-1), i.e. specification of equation (4). The ERRORt-1 in [C] through [G] corresponds to the lagged error term of the cointegration regression as it appears in the 4 rightmost columns of table 3 (i.e. same order and same direction). The numbers in parentheses are $t$-ratios. One $\left(^{*}\right)$ asterisk indicates that the coefficient is statistically different from zero at the $1 \%$ level. "- " means that the variable was not included in the regression. $\Delta$ denotes the first difference operator, i.e., $\triangle P O L_{t}=P O L t-P O L t-1$. 


\section{FIGURE 1: The Classification of Fibers}

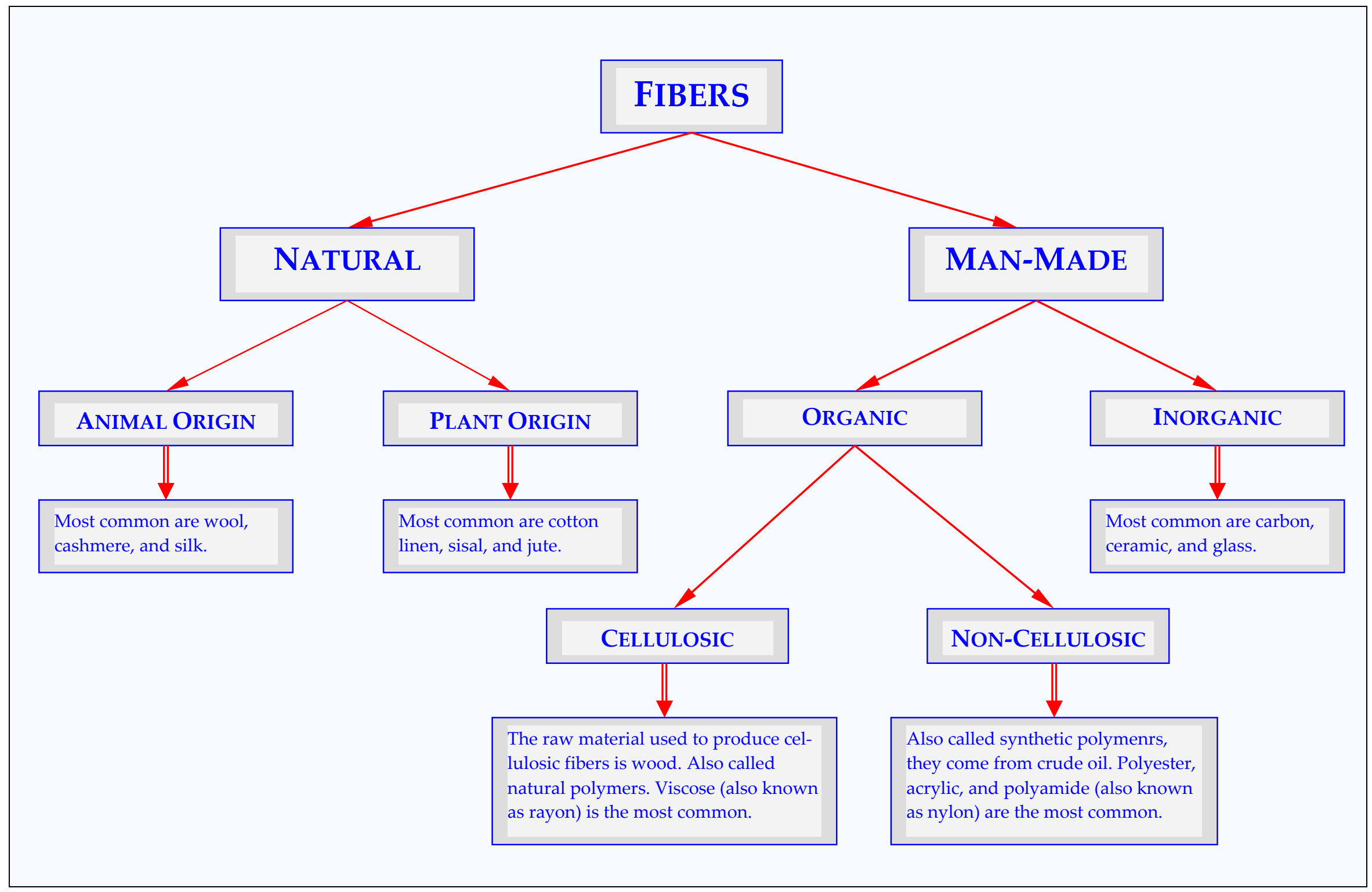


FIGURE 2: Cotton's Share in Total Fiber Consumption and Polyester to Cotton Price Ratio

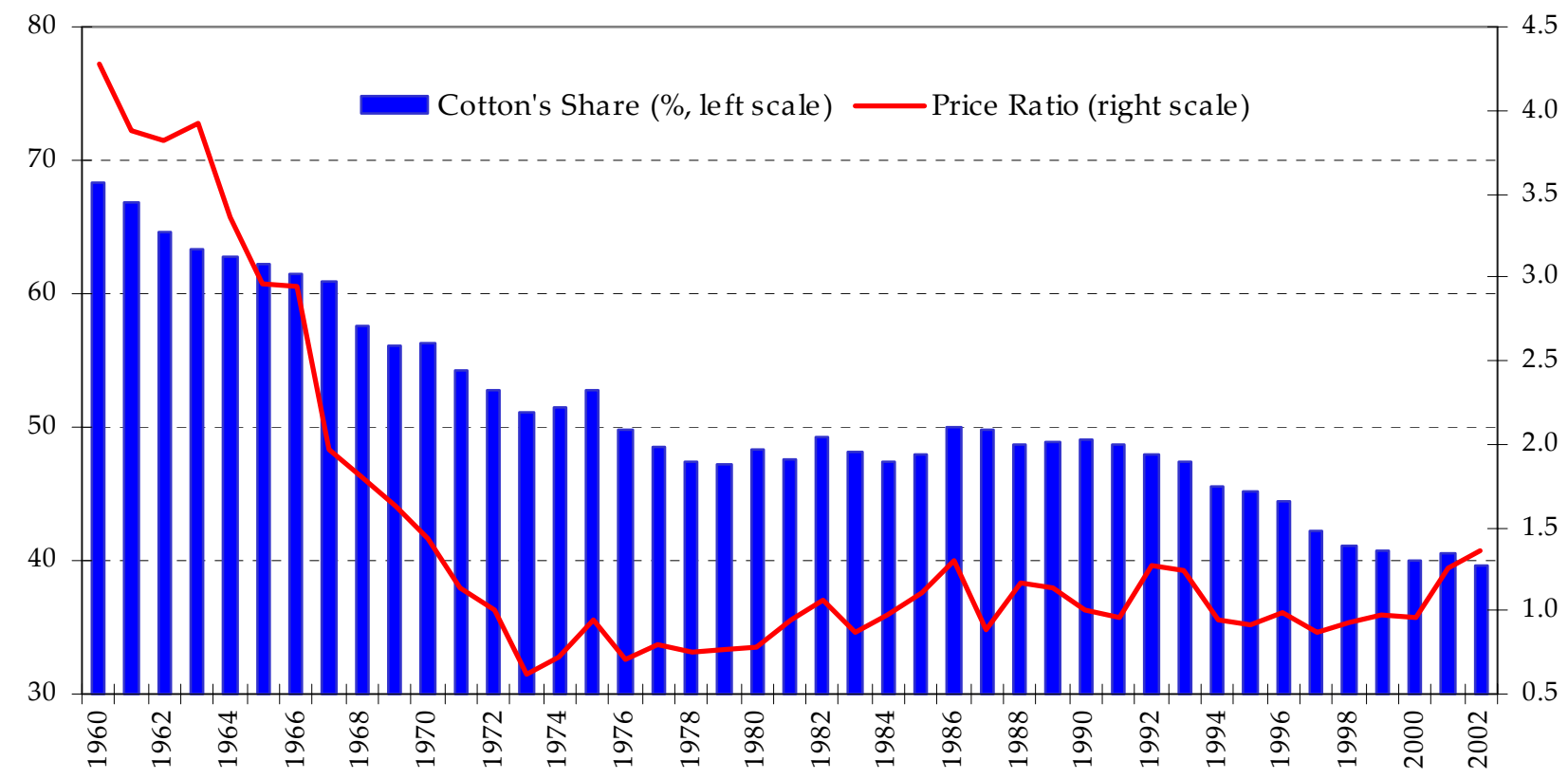

FIGURE 3: Cotton and Polyester Prices (cents/lb.)

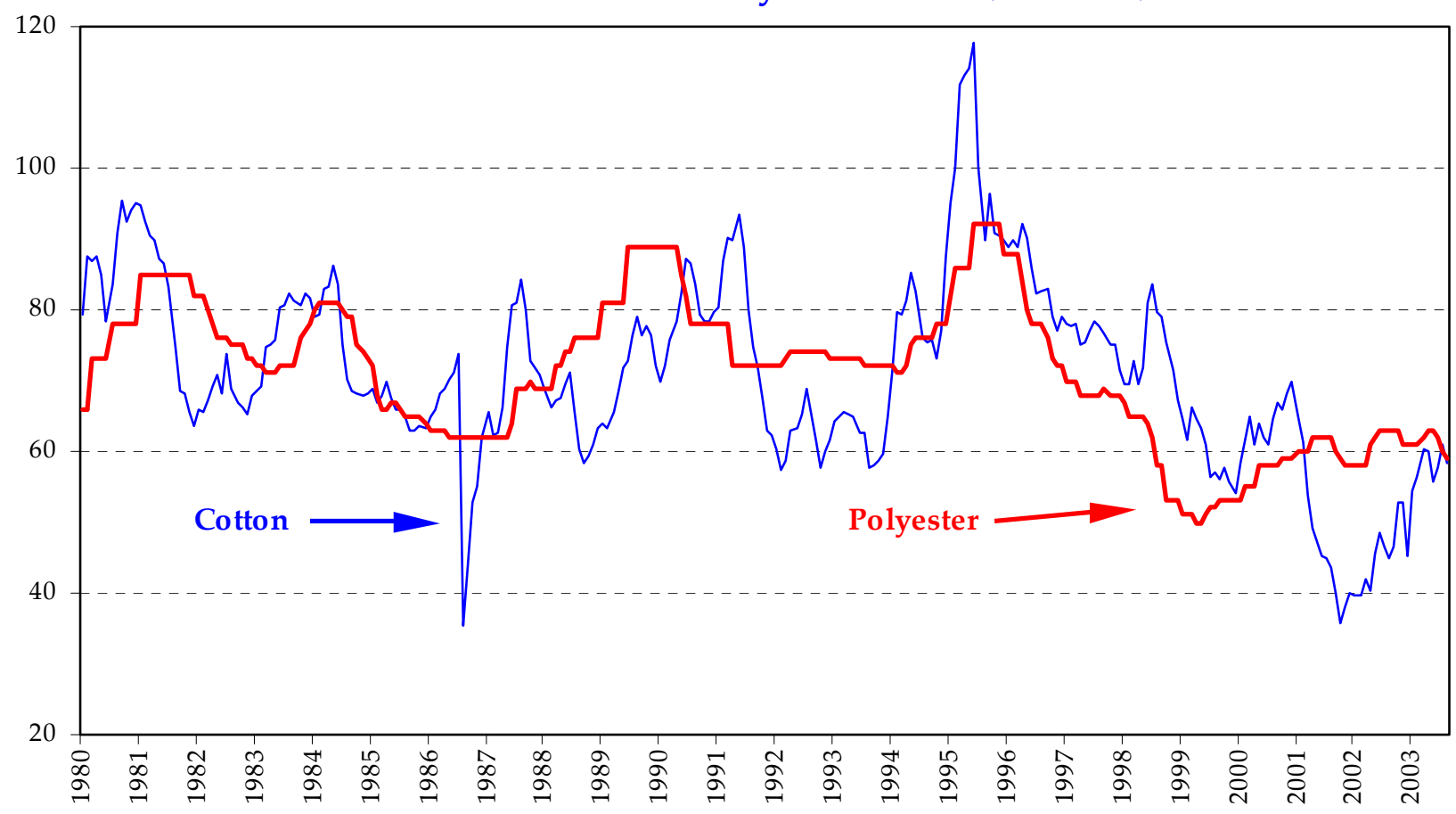


FIGURE 4: Cotton and Crude Oil Prices

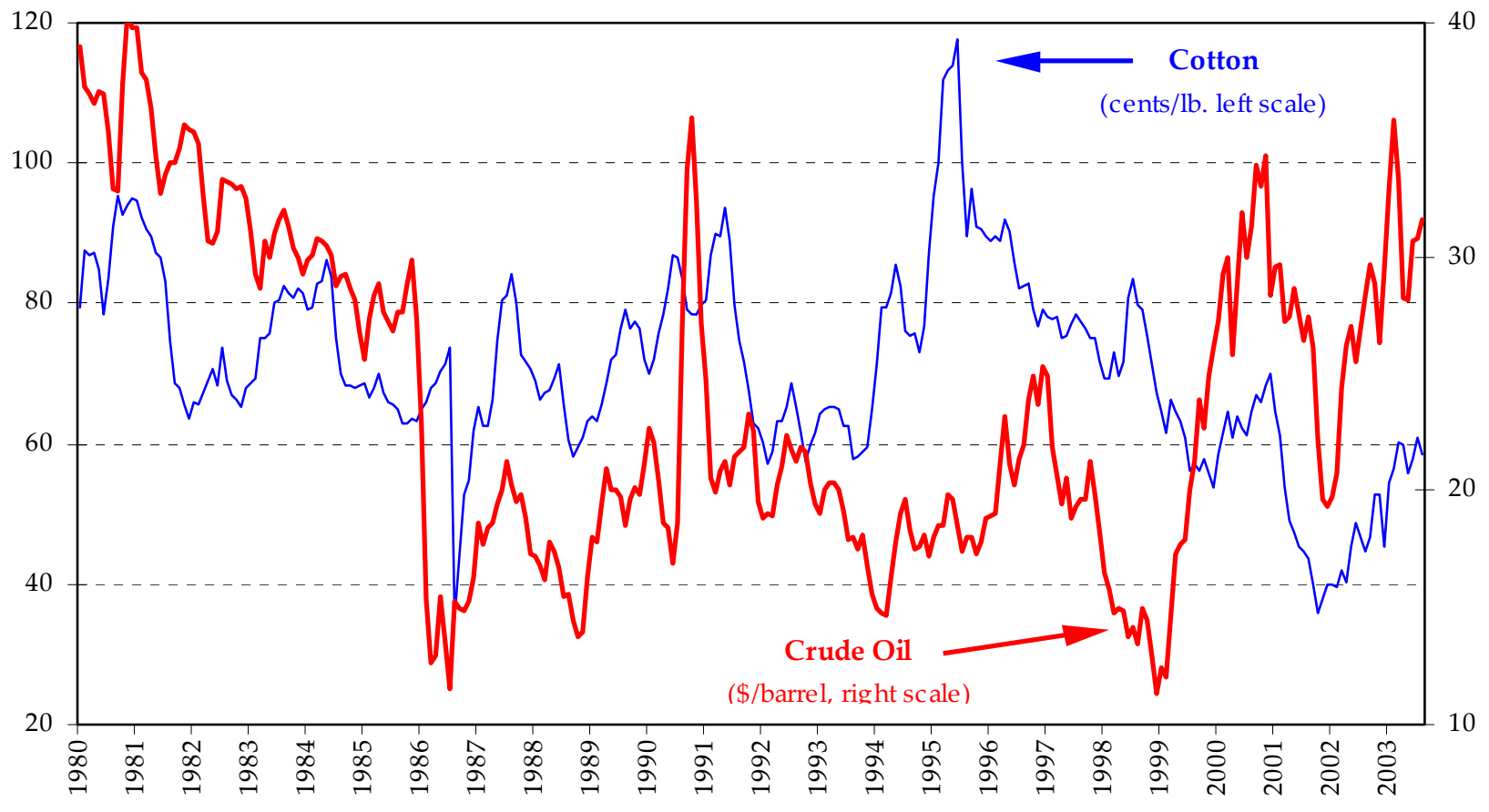

FIGURE 5: Polyester to Cotton Price Ratio

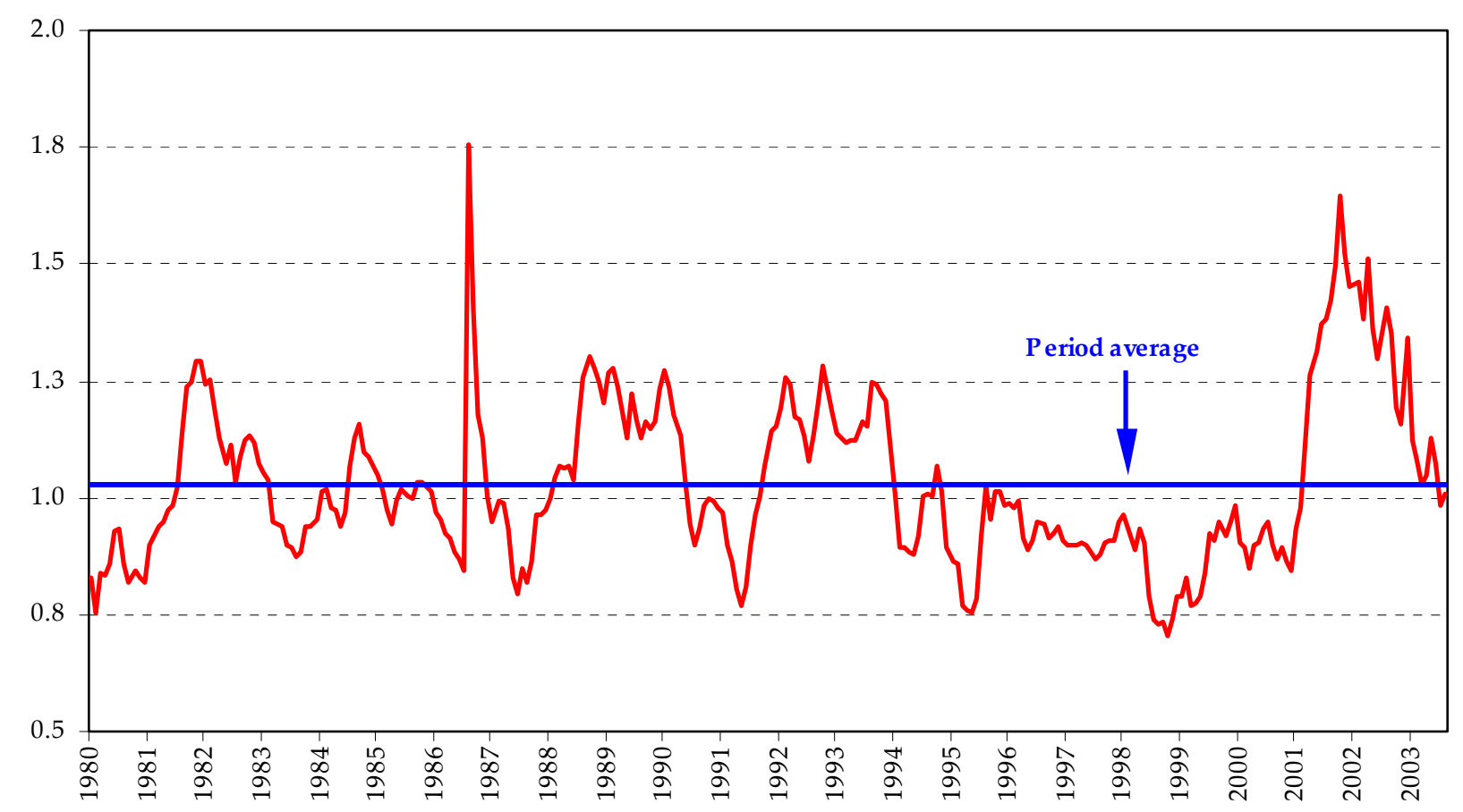


FIGURE 6: R-squares-Cotton Price on other Commodity Prices

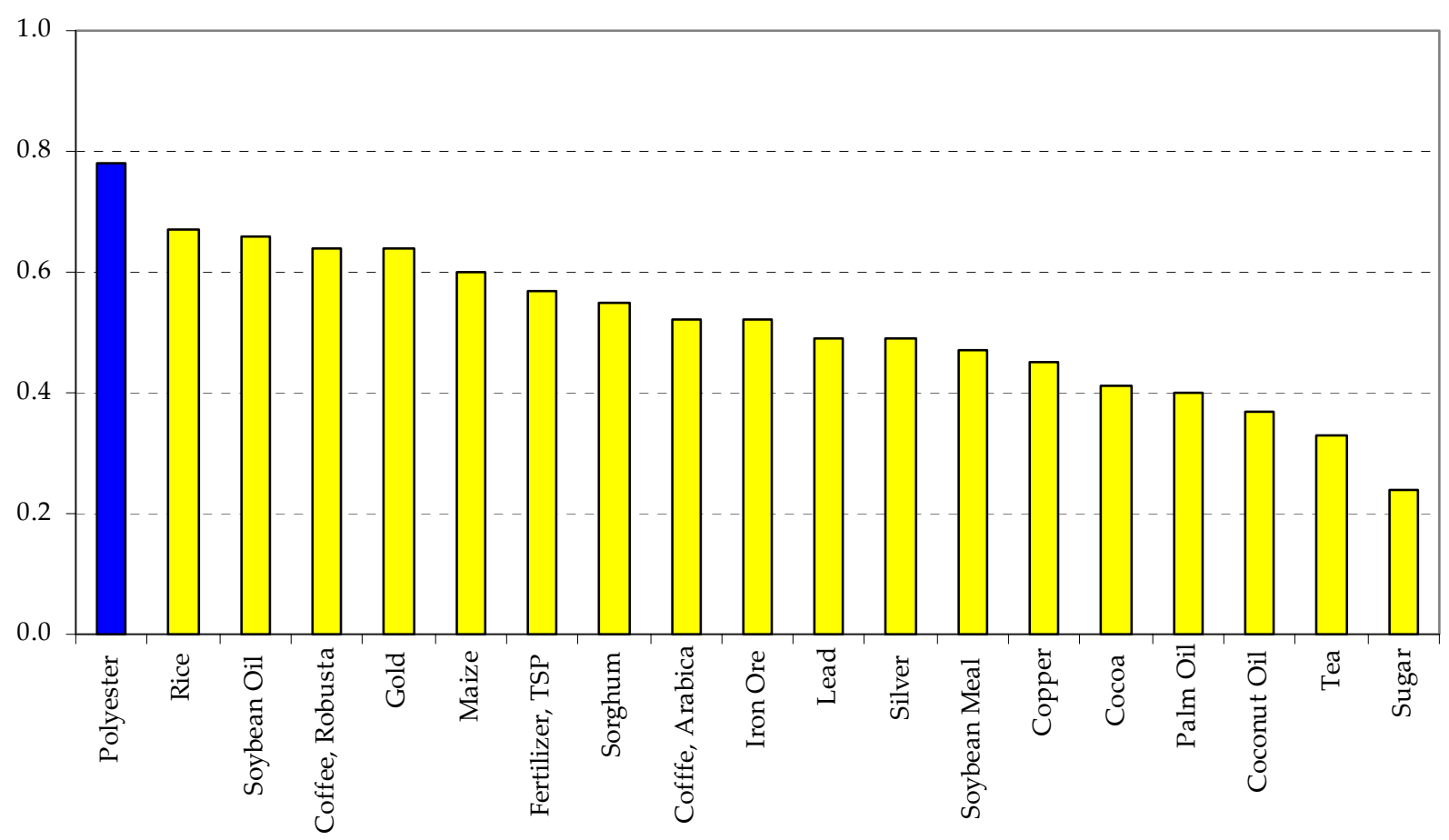

FIGURE 7: R-squares - Polyester Price on other Commodity Prices

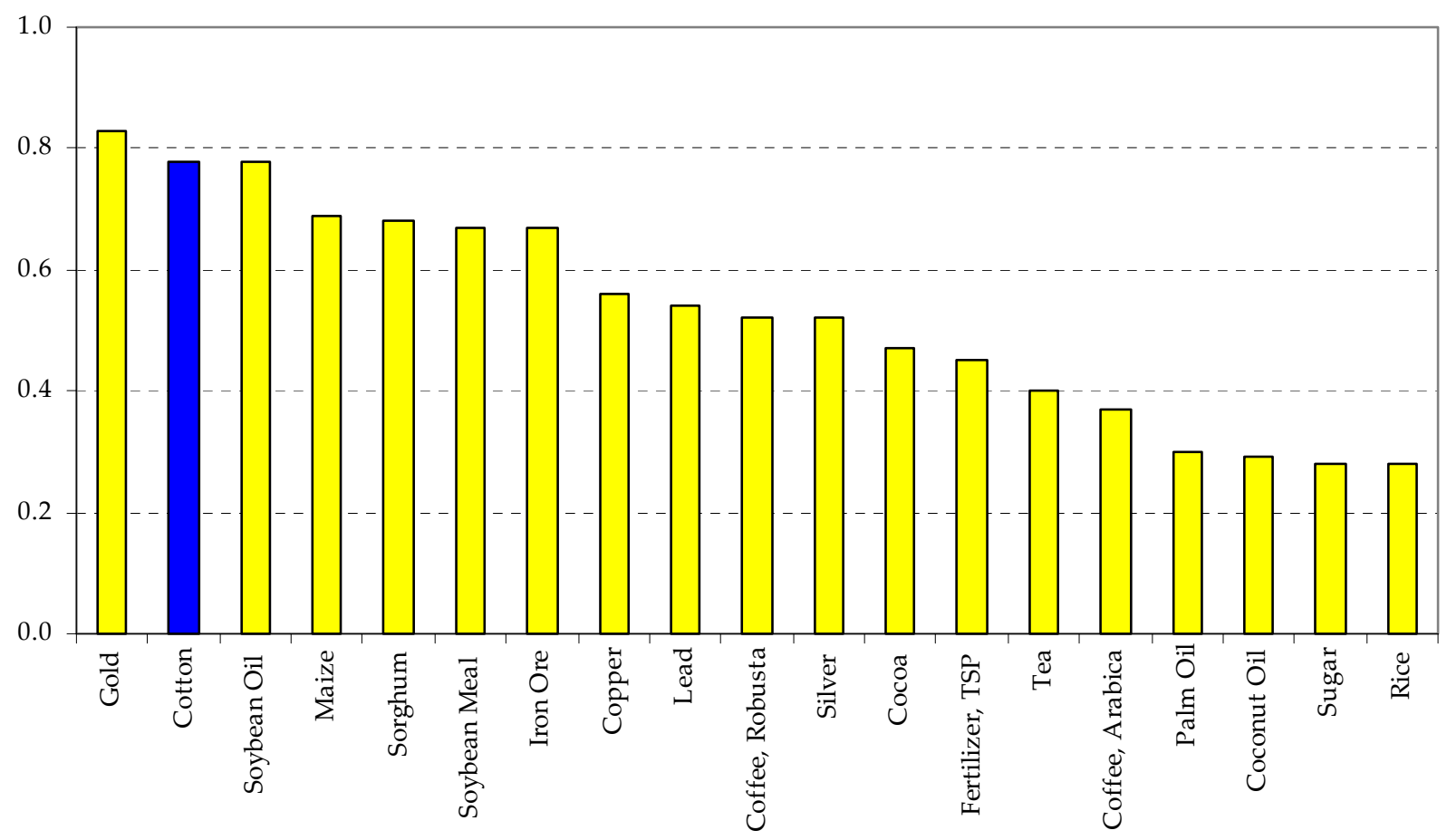




\section{REFERENCES}

Ardeni, Pier Giorgio (1989). "Does the Law of One Price Really Hold for Commodity Prices?" American Journal of Agricultural Economics, vol. 71, pp. 661-669.

Baffes, John (2004). "Cotton: Market Setting, Trade Policies, and Issues." In Global Agricultural Trade and Developing Countries, ed. Ataman Aksoy and John Beghin. The World Bank, Washington, DC.

Baffes, John (2005). "The History of Cotton: From Origin to the $19^{\text {th }}$ Century." In The Cotton Trading Manual, ed. International Cotton Advisory Committee. Woodhead Publishing Limited, London, forthcoming.

Baffes, John (1994). “Does Comovement among Exchange Rates Imply Market Inefficiency?" Economics Letters, vol. 44, pp. 273-280.

Baffes, John (1991). "Some Further Evidence on the Law of One Price: The Law of One Price Still Holds." American Journal of Agricultural Economics, vol. 73, pp. 1264-1273.

Baffes, John and Mohamed Ajwad (2001). "Identifying Price Linkages: A Review of the Literature and an Application to the World Market of Cotton." Applied Economics, vol. 33, pp. 1927-1941.

Baffes John and Anwar Shah (1994). "Causality and Comovement between Taxes and Expenditures: Historical Evidence from Argentina, Brazil, and Mexico." Journal of Development Economics, vol. 44, pp. 311-331.

Barrett, Cristopher B. (1996). "Market Analysis Methods: Are Our Enriched Toolkits Well Suited to Enlived Markets?" American Journal of Agricultural Economics, vol. 78, 825-829.

Campbell, John and Robert J. Shiller (1987). “Cointegration and Tests of Present Value Models." Journal of Political Economy, vol. 95, pp. 1061-1088.

Cashin, Paul, C. John McDermott, and Alasdair Scott (1999). "The Myth of Comoving Commodity Prices." IMF Working Paper WP/99/169. International Monetary Fund, Washington, DC.

Corbae, Dean and Sam Ouliaris (1988). "Cointegration and Tests of Purchasing Power Parity." Review of Economics and Statistics, vol. 70, pp. 508-511.

Deb, Partha, Pravin K. Trivedi, and Panayotis Varangis (1996). "The Excess CoMovement of Commodity Prices Reconsidered." Journal of Applied Econometrics, vol. 11, pp. 257-291.

Dickey, David and Wayne A. Fuller (1979). "Distribution of the Estimators for Time Series Regressions with Unit Roots." Journal of the American Statistical Association, vol. 74, pp. 427-431.

Engle, Robert F. and Clive W. J. Granger (1987). "Co-Integration and Error Correction: Representation, Estimation, and Testing." Econometrica, Vol. 55, pp. 251-276. 
Engle, Robert F. and Byung Sam Yoo (1987). "Forecasting and Testing in Co-Integrated Systems." Journal of Econometrics, vol. 35, pp. 143-159.

Fackler, Paul L. and Barry K. Goodwin (2001). "Spatial Price Analysis." In Handbook of Agricultural Economics, ed. Bruce Gardner and Gordon Rausser. Amsterdam: NorthHolland Publishing Co.

Food and Agriculture Organization (FAO) (2001-02). "Oil Prices and Agricultural Commodity Prices." In Commodity Market Review, Rome.

Fuller, Wayne A. (1976). Introduction to Statistical Time Series. John Willey: New York.

Gardner, Bruce and Karen McConnell Brooks (1994). "Food Prices and Market Integration in Russia: 1992-93." American Journal of Agricultural Economics, vol. 76, pp. 641-646.

Granger, Clive W. J. (1986). "Developments in the Study of Cointegrated Economic Variables." Oxford Bulletin of Economics and Statistics, vol. 46, pp. 213-228.

Hendry, David F., Adrian R. Pagan, and John D. Sargan (1984). “Dynamic Specification." In Handbook of Econometrics, vol. 2, ed. Zvi Griliches and Michael D. Intriligator. Amsterdam: North-Holland Publishing Co.

Isard, Peter (1977). “How Far Can We Push the 'Law of One Price'?” American Economic Review, vol. 67, pp. 942-948.

Johansen, Soren (1988). "Statistical Analysis of Cointegration Vectors." Journal of Economic Dynamics and Control, vol. 52, pp. 231-254.

LeyBourne, S. J., T. A. Lloyd, and G. V. Reed (1994). “The Excess Comovement of Commodity Prices Revisited." World Development, vol. 22, no. 11, pp. 1747-1758.

Mishkin, Fredrik S. (1992). "Is the Fisher Effect for Real? A Reexamination of the Relationship between Inflation and Interest Rates." Journal of Monetary Economics, vol. 30, pp. 195-215.

Mundlak, Yair and Donald F. Larson (1992). "On the Transmission of World Agricultural Prices." World Bank Economic Review, vol. 6, pp. 399-422.

Palaskas, Theodosios B. (1993). "Market Commodity Prices: The Implications of the Co-Movements or Excess Co-Movement Issue." In Economic Crisis in Developing Countries: New Perspectives on Commodities, Trade and Finance, ed. Machilo Nissanke and Adrian Hewitt. New York: Pinter.

Palaskas, Theodosios B. and Panos N. Varangis (1991). "Is There Excess Co-Movement of Primary Commodity Prices? A Cointegration Test." Working Paper Series, no. 758. International Economics department, The World Bank, Washington, DC.

Pindyck, Robert S. and Julio J. Rotemberg (1990). "The Excess Co-movement of Commodity Prices." Economic Journal, vol. 100, pp. 1173-1189.

Phillips, Peter C. B. (1986). "Understanding Spurious Regressions in Econometrics." Journal of Econometrics, vol. 33, pp. 311-340. 
Phillips, Peter C .B. and Mico Loretan (1991). "Estimating Long-Run Economic Equilibria." Review of Economic Studies, vol. 55, pp. 407-436.

Phillips, Peter C. B. and Pierre Perron (1988). “Testing for a Unit Root in Time Series Regression." Biometrica, Vol. 65, pp. 335-346.

Sargan, John D. (1964). "Wages and Prices in the United Kingdom: A Study in Econometric Methodology." In Econometric Analysis for National Economic Planning (Colston Paper No. 16), ed. P. E. Hart, G. Mills, and J. K. Whitaker, London: Butterworths.

World Bank (various issues). "Commodity Price Data: Pink Sheet." Development Prospects Group, Washington DC. 


\section{APPENDIX A: POLYESTER, COTTON, AND CRUDE OIL PRICES}

TAble A1: NOMINAl POlyester PRICES (US CENTS PER POUND), 1980-2002

\begin{tabular}{|c|c|c|c|c|c|c|c|c|c|c|c|c|c|}
\hline & JAN & FEB & MAR & APR & MAY & JUN & JUL & AUG & SEP & OCT & NOV & DEC & ANNUAL \\
\hline 1980 & 66.00 & 66.00 & 73.00 & 73.00 & 73.00 & 73.00 & 78.00 & 78.00 & 78.00 & 78.00 & 78.00 & 78.00 & 74.33 \\
\hline 1981 & 85.00 & 85.00 & 85.00 & 85.00 & 85.00 & 85.00 & 85.00 & 85.00 & 85.00 & 85.00 & 85.00 & 82.00 & 84.75 \\
\hline 1982 & 82.00 & 82.00 & 80.00 & 78.00 & 76.00 & 76.00 & 76.00 & 75.00 & 75.00 & 75.00 & 73.00 & 73.00 & 76.75 \\
\hline 1983 & 72.00 & 72.00 & 71.00 & 71.00 & 71.00 & 72.00 & 72.00 & 72.00 & 72.00 & 76.00 & 77.00 & 78.00 & 73.00 \\
\hline 1984 & 80.00 & 81.00 & 81.00 & 81.00 & 81.00 & 81.00 & 80.00 & 79.00 & 79.00 & 75.00 & 74.00 & 73.00 & 78.75 \\
\hline 1985 & 72.00 & 68.00 & 66.00 & 66.00 & 67.00 & 67.00 & 66.00 & 65.00 & 65.00 & 65.00 & 65.00 & 64.00 & 66.33 \\
\hline 1986 & 63.00 & 63.00 & 63.00 & 63.00 & 62.00 & 62.00 & 62.00 & 62.00 & 62.00 & 62.00 & 62.00 & 62.00 & 62.33 \\
\hline 1987 & 62.00 & 62.00 & 62.00 & 62.00 & 62.00 & 64.00 & 69.00 & 69.00 & 69.00 & 70.00 & 69.00 & 69.00 & 65.75 \\
\hline 1988 & 69.00 & 69.00 & 72.00 & 72.00 & 74.00 & 74.00 & 76.00 & 76.00 & 76.00 & 76.00 & 76.00 & 76.00 & 73.83 \\
\hline 1989 & 81.00 & 81.00 & 81.00 & 81.00 & 81.00 & 89.00 & 89.00 & 89.00 & 89.00 & 89.00 & 89.00 & 89.00 & 85.67 \\
\hline 1990 & 89.00 & 89.00 & 89.00 & 89.00 & 85.00 & 82.00 & 78.00 & 78.00 & 78.00 & 78.00 & 78.00 & 78.00 & 82.58 \\
\hline 1991 & 78.00 & 78.00 & 78.00 & 72.00 & 72.00 & 72.00 & 72.00 & 72.00 & 72.00 & 72.00 & 72.00 & 72.00 & 73.50 \\
\hline 1992 & 72.00 & 72.00 & 73.00 & 74.00 & 74.00 & 74.00 & 74.00 & 74.00 & 74.00 & 74.00 & 74.00 & 73.00 & 73.50 \\
\hline 1993 & 73.00 & 73.00 & 73.00 & 73.00 & 73.00 & 73.00 & 72.00 & 72.00 & 72.00 & 72.00 & 72.00 & 72.00 & 72.50 \\
\hline 1994 & 72.00 & 71.00 & 71.00 & 72.00 & 75.00 & 76.00 & 76.00 & 76.00 & 76.00 & 78.00 & 78.00 & 78.00 & 74.92 \\
\hline 1995 & 82.00 & 86.00 & 86.00 & 86.00 & 86.00 & 92.00 & 92.00 & 92.00 & 92.00 & 92.00 & 92.00 & 88.00 & 88.83 \\
\hline 1996 & 88.00 & 88.00 & 88.00 & 84.00 & 80.00 & 78.00 & 78.00 & 78.00 & 76.00 & 73.00 & 72.00 & 72.00 & 79.58 \\
\hline 1997 & 70.00 & 70.00 & 70.00 & 68.00 & 68.00 & 68.00 & 68.00 & 68.00 & 69.00 & 68.00 & 68.00 & 68.00 & 68.58 \\
\hline 1998 & 67.00 & 65.00 & 65.00 & 65.00 & 65.00 & 64.00 & 62.00 & 58.00 & 58.00 & 53.00 & 53.00 & 53.00 & 60.67 \\
\hline 1999 & 51.00 & 51.00 & 51.00 & 50.00 & 50.00 & 51.00 & 52.00 & 52.00 & 53.00 & 53.00 & 53.00 & 53.00 & 51.67 \\
\hline 2000 & 53.00 & 55.00 & 55.00 & 55.00 & 58.00 & 58.00 & 58.00 & 58.00 & 58.00 & 59.00 & 59.00 & 59.00 & 57.08 \\
\hline 2001 & 60.00 & 60.00 & 60.00 & 62.00 & 62.00 & 62.00 & 62.00 & 62.00 & 60.00 & 59.00 & 58.00 & 58.00 & 60.42 \\
\hline 2002 & 58.00 & 58.00 & 58.00 & 61.00 & 62.00 & 63.00 & 63.00 & 63.00 & 63.00 & 63.00 & 61.00 & 61.00 & 61.17 \\
\hline
\end{tabular}

Source: Cotton Council of America. 
TABle A2: NOMINAl COTTON PRICES (US CENTS PER POUND), 1980-2002

\begin{tabular}{|c|c|c|c|c|c|c|c|c|c|c|c|c|c|}
\hline & JAN & FEB & MAR & $\mathrm{APR}$ & MAY & JUN & JUL & AUG & SEP & OCT & NOV & DEC & ANNUAL \\
\hline 1980 & 79.45 & 87.44 & 86.96 & 87.39 & 84.93 & 78.41 & 83.58 & 90.79 & 95.30 & 92.48 & 93.97 & 95.06 & 87.98 \\
\hline 1981 & 94.65 & 92.33 & 90.54 & 89.71 & 87.31 & 86.48 & 83.20 & 74.83 & 68.61 & 68.06 & 65.67 & 63.57 & 80.41 \\
\hline 1982 & 65.96 & 65.50 & 67.31 & 69.07 & 70.74 & 68.31 & 73.68 & 68.91 & 66.92 & 66.32 & 65.32 & 67.90 & 67.99 \\
\hline 1983 & 68.52 & 69.24 & 74.90 & 75.14 & 75.74 & 80.27 & 80.51 & 82.39 & 81.33 & 80.78 & 82.20 & 81.62 & 77.72 \\
\hline 1984 & 79.08 & 79.45 & 82.88 & 83.25 & 86.27 & 83.73 & 75.05 & 70.14 & 68.37 & 68.23 & 67.99 & 68.29 & 76.06 \\
\hline 1985 & 68.70 & 66.77 & 67.84 & 69.87 & 67.42 & 65.80 & 65.77 & 64.99 & 63.05 & 62.94 & 63.58 & 63.28 & 65.83 \\
\hline 1986 & 64.93 & 66.04 & 68.05 & 68.77 & 70.32 & 71.24 & 73.62 & 35.31 & 44.09 & 52.69 & 54.95 & 61.87 & 60.99 \\
\hline 1987 & 65.41 & 62.41 & 62.69 & 66.31 & 74.70 & 80.57 & 81.13 & 84.23 & 80.02 & 72.65 & 71.66 & 70.72 & 72.71 \\
\hline 1988 & 69.00 & 66.14 & 67.32 & 67.59 & 69.37 & 71.22 & 65.59 & 60.43 & 58.29 & 59.50 & 60.99 & 63.20 & 64.89 \\
\hline 1989 & 64.01 & 63.29 & 65.55 & 68.50 & 71.93 & 72.67 & 76.35 & 79.00 & 76.47 & 77.56 & 76.44 & 72.11 & 71.99 \\
\hline 1990 & 69.91 & 72.02 & 75.59 & 78.44 & 82.27 & 87.05 & 86.70 & 83.65 & 79.22 & 78.29 & 78.50 & 79.79 & 79.29 \\
\hline 1991 & 80.44 & 86.78 & 90.08 & 89.74 & 93.56 & 88.91 & 79.90 & 74.73 & 71.83 & 67.55 & 62.92 & 62.34 & 79.07 \\
\hline 1992 & 60.30 & 57.33 & 58.76 & 63.09 & 63.41 & 65.28 & 68.77 & 65.37 & 61.49 & 57.63 & 59.92 & 61.67 & 61.92 \\
\hline 1993 & 64.18 & 64.82 & 65.41 & 65.13 & 64.99 & 62.73 & 62.57 & 57.80 & 58.02 & 58.79 & 59.54 & 64.96 & 62.41 \\
\hline 1994 & 71.51 & 79.59 & 79.42 & 81.38 & 85.40 & 82.57 & 75.93 & 75.45 & 75.71 & 72.98 & 76.91 & 87.39 & 78.69 \\
\hline 1995 & 95.17 & 100.06 & 111.91 & 113.17 & 113.94 & 117.65 & 100.04 & 89.71 & 96.34 & 90.82 & 90.58 & 89.70 & 100.76 \\
\hline 1996 & 88.86 & 89.76 & 88.79 & 92.10 & 90.20 & 85.99 & 82.18 & 82.61 & 82.99 & 78.96 & 76.89 & 79.14 & 84.87 \\
\hline 1997 & 77.97 & 77.68 & 77.95 & 75.18 & 75.54 & 77.09 & 78.47 & 77.59 & 76.56 & 74.96 & 74.97 & 71.57 & 76.29 \\
\hline 1998 & 69.45 & 69.48 & 72.95 & 69.50 & 71.78 & 80.87 & 83.62 & 79.80 & 79.02 & 75.35 & 71.48 & 67.16 & 74.21 \\
\hline 1999 & 64.47 & 61.67 & 66.31 & 64.69 & 63.17 & 60.87 & 56.24 & 57.14 & 55.98 & 57.79 & 55.88 & 53.94 & 59.85 \\
\hline 2000 & 58.52 & 61.67 & 64.76 & 61.04 & 64.05 & 62.10 & 61.05 & 64.60 & 66.80 & 66.04 & 68.29 & 69.98 & 64.08 \\
\hline 2001 & 64.44 & 61.32 & 53.69 & 49.06 & 47.24 & 45.21 & 44.83 & 43.54 & 40.04 & 35.80 & 38.06 & 39.89 & 46.93 \\
\hline 2002 & 39.79 & 39.65 & 41.92 & 40.40 & 45.46 & 48.60 & 46.53 & 44.83 & 46.54 & 52.76 & 52.71 & 45.38 & 45.38 \\
\hline
\end{tabular}

Source: United States Department of Agriculture. 
TABle A3: Nominal CRUde OIL PRICES (US DOLlaRS PER BARREL), 1980-2002

\begin{tabular}{|c|c|c|c|c|c|c|c|c|c|c|c|c|c|}
\hline & JAN & FEB & MAR & APR & MAY & JUN & JUL & AUG & SEP & OCT & NOV & DEC & ANNUAL \\
\hline 1980 & 39.00 & 37.25 & 37.00 & 36.58 & 37.05 & 37.00 & 35.38 & 32.95 & 32.83 & 37.35 & 40.30 & 39.75 & 36.87 \\
\hline 1981 & 39.77 & 37.90 & 37.60 & 36.37 & 34.28 & 32.71 & 33.51 & 33.98 & 33.99 & 34.61 & 35.68 & 35.41 & 35.48 \\
\hline 1982 & 35.30 & 34.80 & 32.60 & 30.70 & 30.60 & 31.05 & 33.35 & 33.20 & 33.10 & 32.95 & 33.00 & 32.55 & 32.77 \\
\hline 1983 & 31.06 & 29.24 & 28.66 & 30.63 & 29.98 & 30.95 & 31.60 & 31.96 & 31.26 & 30.40 & 30.00 & 29.24 & 30.41 \\
\hline 1984 & 29.84 & 30.08 & 30.73 & 30.63 & 30.45 & 30.04 & 28.79 & 29.17 & 29.30 & 28.64 & 28.16 & 26.70 & 29.38 \\
\hline 1985 & 25.65 & 27.35 & 28.30 & 28.85 & 27.65 & 27.20 & 26.85 & 27.60 & 27.65 & 28.85 & 29.85 & 27.35 & 27.76 \\
\hline 1986 & 22.90 & 15.40 & 12.65 & 12.90 & 15.45 & 13.50 & 11.55 & 15.30 & 14.95 & 14.90 & 15.25 & 16.25 & 15.08 \\
\hline 1987 & 18.60 & 17.75 & 18.45 & 18.65 & 19.40 & 20.05 & 21.30 & 20.20 & 19.50 & 19.85 & 18.85 & 17.30 & 19.16 \\
\hline 1988 & 17.15 & 16.75 & 16.20 & 17.85 & 17.40 & 16.65 & 15.50 & 15.55 & 14.45 & 13.80 & 14.00 & 16.30 & 15.97 \\
\hline 1989 & 18.00 & 17.80 & 19.45 & 20.95 & 20.05 & 20.00 & 19.75 & 18.55 & 19.60 & 20.10 & 19.80 & 21.10 & 19.60 \\
\hline 1990 & 22.65 & 22.10 & 20.40 & 18.60 & 18.45 & 16.85 & 18.65 & 27.15 & 33.70 & 35.90 & 32.30 & 27.15 & 24.49 \\
\hline 1991 & 24.70 & 20.55 & 19.90 & 20.80 & 21.25 & 20.20 & 21.45 & 21.70 & 21.85 & 23.25 & 22.60 & 19.55 & 21.48 \\
\hline 1992 & 18.80 & 19.00 & 18.95 & 20.25 & 21.00 & 22.35 & 21.75 & 21.30 & 21.90 & 21.70 & 20.35 & 19.40 & 20.56 \\
\hline 1993 & 19.05 & 20.05 & 20.35 & 20.30 & 20.00 & 19.15 & 17.90 & 18.00 & 17.50 & 18.15 & 16.75 & 15.55 & 18.56 \\
\hline 1994 & 15.00 & 14.75 & 14.65 & 16.30 & 17.85 & 19.05 & 19.65 & 18.35 & 17.45 & 17.65 & 18.10 & 17.16 & 17.16 \\
\hline 1995 & 17.99 & 18.53 & 18.54 & 19.87 & 19.64 & 18.50 & 17.42 & 17.96 & 18.03 & 17.30 & 17.79 & 18.83 & 18.37 \\
\hline 1996 & 18.89 & 19.07 & 21.16 & 23.20 & 21.15 & 20.27 & 21.36 & 21.97 & 23.92 & 24.94 & 23.66 & 25.32 & 22.08 \\
\hline 1997 & 24.93 & 21.83 & 20.66 & 19.40 & 20.50 & 18.84 & 19.30 & 19.62 & 19.59 & 21.21 & 19.88 & 18.16 & 20.33 \\
\hline 1998 & 16.51 & 15.81 & 14.76 & 15.01 & 14.90 & 13.71 & 14.12 & 13.40 & 14.98 & 14.42 & 12.96 & 11.31 & 14.32 \\
\hline 1999 & 12.48 & 12.01 & 14.66 & 17.34 & 17.75 & 17.89 & 20.07 & 21.25 & 23.86 & 22.64 & 24.85 & 26.08 & 19.24 \\
\hline 2000 & 27.27 & 29.28 & 29.92 & 25.84 & 28.83 & 31.86 & 29.97 & 31.31 & 33.89 & 33.05 & 34.37 & 28.39 & 30.33 \\
\hline 2001 & 29.55 & 29.62 & 27.24 & 27.42 & 28.61 & 27.57 & 26.44 & 27.45 & 26.12 & 22.18 & 19.59 & 19.31 & 25.93 \\
\hline 2002 & 19.69 & 20.72 & 24.38 & 26.24 & 27.04 & 25.51 & 26.92 & 28.37 & 29.67 & 28.85 & 26.28 & 29.50 & 26.10 \\
\hline
\end{tabular}

Source: World Bank. 